\title{
Governmental Fictions: The Naturalist Novel and the Making of Population in Fin-de-Siècle Brazil
}

\author{
Carlos Gustavo Halaburda \\ Northwestern University
}

\section{The Governmentality of the Novel}

In the preface to his novel Flor de sangue (1897), Valentim Magalhães (1859-1903), a prominent man of the cultural elite and one of the founding members of the Brazilian Academy of Letters, cited the following lines by the French naturalist writer Edmond de Goncourt (1822 -1896).

\begin{abstract}
Hoje que o romance se alarga e cresce, que vai sendo a grande forma séria, apaixonada, viva, do estudo literário e do inquérito social, que se vai tornando, pela análise e pela pesquisa psicológica, a história moral contemporânea, hoje que o romance se impôs aos estudos e aos deveres da ciência, ele pode também reivindicar suas liberdades e privilégios (5).
\end{abstract}

With these words, Magalhães wished to display his vision of the social role of the novel. He considered it a form of intellectual inquiry linked to science, morals, and good conduct. Inspired by Gouncourt, Magalhães saw the novel as a narrative form capable of sharing the authority of science to study the social field and create a model citizenry: "Os romances sinceros e verdadeiros, isto é: honestos e morais não se escrevem para serem lidos por donzelas e donzêis" (4). Sincerity and honesty, truth and morality were ideal values to be held by the mothers and fathers of the nation, who were given the task to administer the reading of books: "Aos pais, às mães e aos maridos compete proibir a leitura [dos romances] aos rapazes e às raparigas, para quem um livro de medicina também podia ser perigoso" (4-5). Magalhães did not make distinctions between medical knowledge and aesthetic materials, between a medicine book and a novel: it was dangerous for children to explore on their own the inner secrets of their biology. In Magalhães' view, as well as for the vast majority of naturalist writers in Brazil, fiction was part of the many strategies to create responsible citizens and a Victorian subjectivity of respectability.

In this article, I want to explore three Brazilian fin-de-siècle novels that inaugurated a true aesthetic revolution that would have as its main subject of interest the governmentality of bourgeois conduct. A carne (1888) by Julio Ribeiro, A intrusa (1908) by Júlia Lopes de Almeida, and Hóspede (1887) by Pardal Mallet allow an examination of how the novel in turn-of-thecentury Brazil assumed a governmental strategy of sex. I argue that these nation-building writers/pedagogues promoted a program of sexual conduct oriented toward the conservation of the institutionality of marriage, family, 
and reproduction. I demonstrate how female education not associated with the domestic space, inter-class marriage, promiscuity, and adultery were portrayed as transgressions against the biological futures of patrician circles.

\section{Governmentality and Literature}

In Foucauldian scholarship, governmentality names a type of power devoted to the conduct of conducts. It takes into account that government is a broad and complex phenomenon that is not limited to the exclusive role of the state as a regulator of institutions and systems. In the government of populations, social groups, individuals, and associations are involved in the construction of governmental networks that emerge in specific contexts. Governmentality is a field of inquiry that traces the origins and reasons of a power dedicated to the administration of biological cycles, health, education, and the levels of strength and productivity of the population understood as a multiple body.

In Security, Territory, Population (2007), Foucault shows that while the forms of sovereign, disciplinary and biopolitical power enabled the investigation of war conflicts, the disciplining of individuals, state racism and the management of the life and death of populations, governmentality focuses on the notions of conduct and government. As Williams Walters points out, Foucault's history of governmentality highlights three main arts of government: pastoralism, the raison d'etat, and liberalism. Pastoralism refers explicitly to the government of conduct, a technique that, in the West, goes from the ancient Hebrew tribes to the emergence of the bourgeois family and the modern state. Raison d'etat refers to an art of government that conjugates the exercise of sovereignty with pastoralism, a union that gives birth to the modern state as a new apparatus for the organization of human groups (Walters 25). Armies, police, schools, and other institutions would shape a doctrine that Foucault calls the modern state (Lemke 23). Liberalism, finally, defines an art of government that requires the least possible government, a regime of truth allied to the logic of the market that would have a direct role in liberal governments (Lemke 30-31).

Within this trajectory, it is evident that the lectures of 1977-78, Security, Territory, Population, and of 1978-79, The Birth of Biopolitics, suppose a retreat of the theory of individual discipline as the main model of power in Foucault's genealogy. Instead, the population emerges as the form that individuals take when they enter into the networks of statistics and reproductive diagrams for the optimization of life. The family becomes the threshold of connection between individuals and the population, "a site of exchange between individuality and collectivity", an apparatus of government and management of the reproductive policies of the modern state. For Foucault, it is through the family where biopolitics and governmentality merge (Lemke 11-12).

The management of life generates a normative order of the human. Biopower objectifies life to control its excesses and differences, and within this normalization paradigm emerges the production of serialized living beings. The management of life turns into an art of government, a governmentality, type of power that arises in the eighteenth century that "has the population 
as its target, political economy as its major form of knowledge, and apparatuses of security as its essential technical instrument" (Security 108).

I am interested in the history of governmental power outlined by Foucault $(1992,2003,2007)$ and continued by a large corpus of scholarship on governmental biopolitics (Agamben 1998, 1999; Butler 2006), governmentalities of populations (Walters 2012), and queer theory and reproductive life (Edelman 2004; Deutscher 2017) to think about what Foucault's European archive of governmental strategies did not address. By focusing on the Brazilian case, I want to emphasize how world literatures outside of the perimeters of Europe can be studied as materials of culture that had an active role in the government of populations. A literary inquiry that goes beyond the manuals of conduct, statistiscal reports, medical treatises, and legal cases explored by Foucault in his lectures at the Collège de France, I want to claim, can show how the naturalist novel in Brazil produced its own governmental fictions and power strategies to implement ideal behaviors and normative sexualities, particularly in elite circles.

\section{Imperatives of Reproduction: A carne}

In 1888 , the philologist and novelist Julio Ribeiro (1845-1890) published A carne [The Flesh], one of the most polemical and harshly criticized cultural productions in fin-de-siècle Brazil. The story about a young paulista woman who engages in an illicit affair with an older man and who conceives a child outside of conyugal life received overt rejection from the clergy of São Paulo in the voice of the priest Sena Freitas. The novel was accused of propagating pornography and of attacking national morals (de Oliveira 1341). Literary critics, on the other hand, trivialized it for being superficial and technically flawed: renowned critics José Veríssimo and Alfredo Pujol dismissed it as a bad copy of the French model. The critic Lucélia Rodrigues de Oliveira notes, "Aos olhos da crítica, o romance criado por Júlio Ribeiro apresentou apenas "um exibicionismo sensual". Nomes como José Veríssimo e Alfredo Pujol lançaram considerações nada generosas ao mesmo" (1343). And yet, like many other pieces of transnational naturalism, $A$ carne was a moral fable shaped by an epistemological skeleton already defined by science under the light of Social Darwinism and the European theories of degeneration. In addition, Emile Zola's experimental method, despite its fragmented and complex reception in the Southern Cone, informed and influenced naturalist writers eager to portray the social maladies that resulted from modernization (Braga-Pinto 151).

Degeneration theory, whose origins can be traced to mid-nineteenth century French psychiatry, spread in South America to argue that social upheaval could be explained through hereditary traits. In this sense, this theory pursued the optimal reproduction of the human species, that is, the proliferation of strong and productive populations, immune to the contact with bodies that carried the stigmas of inherited mental illnesses (Scull 193). In Degeneration (1892) physician Max Nordau (1849-1923) reexamined the studies of Bénédict Augustin Morel (1809-1973) about the traditional etiology of degeneration that highlighted the negative impact of ingesting toxic substances for human health. Instead, Nordau argued that the new 
decadent arts, modern life, and urbanization had produced a new symptomatology. Fin-de-siècle literature, he noted, was the work of degenerates and "the enthusiasm of their admirers [was] the manifestation of more or less pronounced moral insanity, imbecility, and dementia" (viii). Nordau's theory was part of a larger transnational Western network of clinical knowledges and aesthetic experiments that conjugated the concerns of social hygiene and of eugenics, forms of knowledge grouped in South America under the rubric of social medicine. The new medical paradigm sought to promote the welfare of the population "beyond the simple sum of the well-being of each individual member" (Miranda and Vallejo 563. My translation). Social hygiene aimed at the control and treatment of anomalies, diseases, and pathogens while eugenics promoted processes of selection to eradicate malignant bodies.

Clinical jargons revolutionized the Brazilian cultural circles. Responding to the scientific scheme of the time, the novel began to participate in scientific controversies. Novels populated the pages with new families of barbarism that generated stories of never seen before aesthetic horizons concerned with the future of the species. Zola's transnational schools aimed at studying how the natural body was subjected to physio-chemical processes that impacted on the behavior of subjects tormented by their nerves, their blood, and their flesh. In the second preface to his novel Thérèse Raquin (1867), Zola declared that his story was "a study of temperaments and not characters" (vi). He had "selected personages sovereignly dominated by their nerves and their blood, destitute of free will, led at each act of their life by the fatalities of their flesh" (vi).

The European theories of hereditary degeneracy had a vast circulation and produced in Brazil prestigious medical figures fascinated with criminology's psychiatric fictions. By the end of the nineteenth century, a survey of criminal anthropology, Nova Escola Penal [The New Penal School] had generated a new series of scientific principles to study transgressive human behaviors (Braga-Pinto 153). In this sense, Ribeiro's novel belongs to a larger corpus of ideas about sexuality that the author turned into a privilege source for investigating Brazilian society's private life. Ribeiro shared Zola's views that the union between aesthetics and the scientific observation of human life would allow the study of how the moral decay of the masses put at stake the reproductive futures of Wester Civilization. Zola's naturalism diagnosed the social body as a sick entity that required the truths of science to prevent and eradicate sexual perversions and other ills. As Sabine Schlickers argues "it should be noted ... that in the fictional world of The Rougon-Macquart, purely sexual practices, without procreative ends were always discredited as chute, faute, perversion, promiscuité, prostitution, etc" (34. My translation).

Ribeiro, who dedicates $A$ carne to Zola, would align his aesthetic program with the French writer's politics of reproduction. For renowned Brazilian critic Araripe Jr, Ribeiro had written a novel that spoke of the low passions of a woman carried out by "as furias da carne", giving an acceptable naturalist example of a physiological fiction (123). Indeed, in A carne, the industrialization of sexuality is evidenced through the portrayal of the female body as an object of fascination- a body destined to the study of its desires and to 
fulfill the patriarchal requirements of expanding the pool of national progeny and educating future generations of white masters.

As a wealthy young lady from the city of São Paulo, Lenita, the protagonist, receives a privileged liberal education, which becomes a concern for the narrator. Lenita expresses disinterest in the prospect of becoming a maternal figure and a pious wife. After her father dies, she moves to the fazenda of a close friend of the family. Once there, aroused by illicit desires, she maintains a clandestine relationship with the fazendeiro Manuel Barbossa. But, at the end of the novel, Lenita leaves the old man, the father of her future child, for a wealthy suitor from São Paulo, avoiding the scandal of a pre-marital pregnancy. Barbossa would take his own life.

Lenita is invested by the narrator with a power of life. Her reproductive capacity turns her into a live instrument capable of ensuring national futures. The narrator's task would be then to stimulate the female sex to produce life and guarantee the biological continuity of the nation's rulers. The reproductive scene would show the protagonist's erotic passions for a male bronze statue:
E tinha ímpetos de comer de beijos as formas masculi- nas estereotipadas no bronze. Queria abraçar-se, queria confundir-se com elas. De repente corou até à raiz dos cabelos. Em um momento, por uma como intussuscepção súbita, aprendera mais sobre si própria do que em todos os seus longos estudos de fisiologia. Conhecera que ela, a mulher superior, apesar de sua poderosa mentalidade, com toda a sua ciência, não passava, na espécie, de uma simples fêmea, e que o que sentia era o desejo, era a necessidade orgânica do macho... Com movimentos sacudidos, nervosos, atirou o xale, desabotoou rápida o corpete, arrebentou os coses da saia preta e das anáguas, ficou em camisa. Uma larga mancha vermelha, rútila, viva, maculava a alvura da cambraia. Era a onda catamenial, o fluxo sangüíneo da fecundidade que ressumava de seus flancos robustos como da uva esmagada jorra o mosto nubente (11).

Stimulation, pleasure, and cycles of fecundity comform a coherent triad for the narrator, who finds no other destiny for the female sex than to put its tissues and blood at the service of procreation. Lenita is taken by her "animal" nature. She is written first of all as a species, "uma simples fêmea" with irrepressible physiological needs. Her masturbatory pleasures compete with the imperatives of a strictly reproductive sexuality. Her desires would be soon disciplined by a clinical narrator that appears as a custodian of the female body and who would ensure the futures of reproduction for the elite. The natalist gaze is distributed in Ribeiro's governmental fiction to ensure that the reproductive cycles of the woman are fulfilled.

Forms of sexuality that compete with the imperatives of fecundity would be presented as barbarism. The text condemns sporadic pleasures as primitive 
and pathological. In the following scene, Ribeiro presents Lenita as possessed by a sadistic spectacle: the flogging of a black slave,

O negro deu um corcovo; irrompeu-Ihe da garganta um berro de dor, sufocado, atroz, que nada tinha de humano. Desmaiou. Lenita sentia um como espasmo de prazer, sacudido, vibrante; estava pálida, seus olhos relampejavam, seus membros tremiam. Um sorriso cruel, gelado, arregaçava-Ihe os lábios, deixando ver os dentes muito brancos e as gengivas rosadas. O silvar do azorrague, as contrações os gritos do padecente, os fiar de sangue que ela via correr embriagavam-na, dementavam-na, punham- na em frenesi: torcia as mãos, batia os pés em ritmo nervoso. Queria, como as vestais romanas no ludo gladiatório, ter direito de vida e de morte; queria poder fazer prolongar aquele suplício até à exaustão da vítima; queria dar o sinal, pollice verso, para que o executor consumasse a obra. E tremia, agitada por estranha sensação, por dolorosa volúpia. Tinha na boca um saibo de sangue (26).

Lenita suffers vibrating spasms in her body infatuated by the spectacle of flogging. Perverted by the sadistic ritual of slavery, she showcases signs of primitivism as she wishes to prolong the suffering of the slave while blood comes out of her mouth as if she were a beast. The bestialization of the young woman appears as the impending result of her sexuality subordinated to her intellectual enterprises. The neglect of her physiological needs had ended in the debauchery of her flesh. Without a normative, understandable, managed, calculable reproductive sexuality, there seems to be no white national woman but a monster. The hypererotization of the white woman captivated by the masochistic visions stages a conversion and a corruption: Lenita's body becomes racialized, as she loses the traits that define whiteness. Away from representing virtue and motherhood, the young woman integrates into her body traits associated to blackness: "sexuality, nudity... and indolence" (de Souza 278). As Julianna Rosa de Souza argues, for nineteenth-century scientific racism blackness implied "the hypersexualization of the body, highlighting virility for men and seduction for women (278). Moreover, as scholars of the naturalist novel argued, in most of fin-de-siècle novels of the Brazilian catalogue such as O bom crioulo (1888) by Adolpho Caminha (1867-1897), blackness was associated with irrepressible desires and non-reproductive sexuality (Braga-Pinto 152). Lenita's white body, saturated with images of violence and perversion, appears as a symptom in Ribeiro's narrator that cautions about the urgency to govern the illicit desires of the paulista elite.

Plotted as a cautionary tale, the novel reacts against liberal education across genders. The story suggests that white women who nourish their intellect would end up engaging in sadistic pleasures that arise from ignoring the obligation to carry out their reproductive mission. When Lenita drops her studies after the death of her father, she would recuperate her femininity:

E Lenita sentia-se outra, feminizava-se. Não tinha mais gostos viris de outros tempos, perdera a sede de ciência: 
de entre os livros que trouxera procurava os mais sentimentais...Tinha uma vontade esquisita de dedicar-se a quem quer que fosse, de sofrer por um doente, por um inválido. Por vezes lembrou-Ihe que, se casasse, teria filhos, criancinhas que dependessem de seus carinhos, de sua solicitude, de seu leite. E achava possível o casamento. A imagem do pai ia-se esbatendo em uma penumbra de saudade que ainda era dolorosa, mas que já tinha encanto. (10)

Sentimental literature cures Lenita's symptomatology and attacks of hysteria. She becomes feminized when she turns away from the knowledges and techniques of government reserved for white men. In the narrator's logic, when the woman learns her place in the universe of gender relations and of knowledge production, it arises in her a "natural" desire to be a caretaker, to be married, to be a mother- a desire for responsibility associated with her reproductive and moral duty for the nation. The white Brazilian woman appears as an invention of the patriarchal regime. The novel works as a mechanism of supervision, control, and government of the reproductive agency of the protagonist.

A carne's reproductive scenes celebrate the control of the biological cycles, health, education, and the levels of strength and productivity of the Brazilian national family. The female body is written as the territory where familiar and common dreams of prosperity are entangled. Ribeiro's text suggests that both scientific knowledge and casual pleasures should be attenuated and managed through the presence of the reproductive phallus. As a governmental fiction of the white female body seen as a source of power and wealth, A carne constitutes an essential document of Brazilian fin-desiècle culture. It can be argued that the national woman is written as a living machine, whose industrial-anatomic power could guarantee the biological continuity of white political supremacy in the aftermath of the abolition of slavery (1888). Indeed, the future of race relations had become uncertain by the end of the century. As César Braga-Pinto notes, the late 1880 s saw a "growing concern with... the fate of the black man in the aftermath of the abolition of slavery" (Braga-Pinto 167). Class, race, and gender relations in post-abolition Brazil would witness a dramatic transformation as literature would capture another body that threatened to extend its transgression and make the homeland insecure for the upper classes: the urban proletariat.

\section{The Triumph of Victorian Conduct: $A$ intrusa}

Towards the end of the nineteenth century, stories of physiological themes such as $A$ carne and the classic novels $O$ mulato (1881) and O cortiço (1890) by Aluísio Azevedo (1857-1913) begin to have less protagonism. The idea that the novel could speak the language of sociology and economics would instead prevail. Physiology would be replaced as the main framework to explain national conflicts through literature. The critic Flora Süssekind traces this genealogy in her literary history of Brazilian naturalism. She stresses how the cultural critique of the late nineteenth century saw that the French naturalist method, especially that of the biological model, was contributing 
to a concealment of social inequalities. Süssekind points out a new union: that of literature with economy: if science was "o instrumento privilegiado para falar sobre o pais" (85) by the beginning of the twentieth century physiological explanations start to fade away. In literary culture, the pathological phenomena give space to a socio-economic perspective, creating "uma modificação da perspectiva na interpretação do país" (85).

A intrusa (1908) by Júlia Lopes de Almeida (1862-1934) comes to give expression to this shift. The novel tells the story of an aristocratic family. The critical gaze would be upon a new historical subject: the servant, a figure that reaches its protagonism after the abolition of slavery in the Brazilian cultural archive. The construction of this character does not originate so much in the pathologizing language characteristic of $A$ carne, but in the moral scrutiny of the servant's conduct based on traditional class values. Almeida holds a nostalgic perspective of the traditional world governed by the imperial aristocracy. Thus, the language of melodrama gives way to the indulgence of strong emotional pictures and moral polarizations to antagonize the social classes. Almeida seems to present a nostalgic romanticism of the imperial order. She critiques the new political design of the First Brazilian Republic (República Velha) while mourning the decline of the nobility.

In "O demônio familiar" (2007), the critic Sônia Roncador explored how in Almeida's early writings there is a a clinical gaze that looks at the servant as a carrier of contagious diseases such as cholera, yellow fever, and syphilis. Almeida held a decadent vision of the female proletarian class. She saw in washerwomen and wet nurses a source of danger. They were potential carriers of illnesses typical of the spaces that they inhabited: the slums of Rio de Janeiro that sprouted with the housing crisis that Brazilian modernization had generated. Almeida presents herself as a fervent militant of the bourgeois project of civilizing (whitening) the domestic space. Roncador concludes that these images of servants as criminals and disease carriers "serve Almeida's pedagogical project to prepare Brazilian women to successfully fulfill their new responsibilities as dedicated mothers, spouses and housewives in Republican Brazil" (94).

Roncador studies, mainly, how Almeida describes the new regime of free domestic labor as threatening to the health of the new family configuration under the Republic (95). This concern for the future of the bourgeois family is also identified by Michel Foucault as an anxiety to preserve the moral order of the Victorian regime, so obsessed with drawing the boundaries between normality and abnormality in the areas of morals and psychiatry. Foucault examines the problematic place of the servants and other intermediaries in children's education. The possibility of an early sexual awakening could bring a mismatch to the family as a bourgeois apparatus of social organization, discipline, and government:

it may be a deliberate stimulation, more perverse than careless, by nurses, for example, who want to get children to sleep. It may be pure and simple seduction by servants, private tutors, and teachers. The whole campaign against masturbation is very quickly directed, we can say 
from the start, against the sexual seduction of children by adults, and not just by adults, but by those belonging to the child's immediate circle, that is to say, by all those who at this time were statutory figures of the household. Servants, governesses, private tutors, uncles, aunts, and cousins will all come between the parents' virtue and the child's natural innocence and introduce a dimension of perversion (Abnormal 244).

Such "dimension of perversion" concerns the Brazilian aristocracy in $A$ intrusa. Alice Galba, the governess hired by the lawyer and widower Argemiro Claudio to take care of her daughter, Maria da Gloria, soon becomes suspicious for the baroness of Cerro-Alegre, the lawyer's mother-in-law. The novel provides images of the daily lives of a social class in its decline that sees the multiplication of intrusive figures capable of perverting a rigid class design.

After losing his wife Maria, the daughter of the barons of Cerro-Alegre, Argemiro's main responsibility is the education of her young daughter. The girl lives with her grandparents in a fazenda at the outskirts of Rio de Janeiro. The lawyer feels that the education of the eleven-year-old girl under the care of the barons has no future in the society to come: "-É uma selvagem... esta é que é a verdade; mal sabe lêr, rabisca umas letras em pessima calligraphia... e toca sem compasso umas intoleraveis liçoes do methodo! Já era tempo de saber muito mais. Não te parece?", asks the man to the mother-in-law (28); "a verdade é que a Gloria já chegou a uma edade em que não deve ser tratada como o animalzinho amimado que é. Precisamos preparal-a para o futuro, que é sempre incerto (51), the lawyer warns the Baroness.

Argemiro's life goes on with deep unhappiness, between the boredom of enduring his existence around unfaithful servants, and the frustration of seeing his daughter becoming an "animal" due to the lack of proper instruction. He decides to hire a mysterious young woman who responds to his job post in a newspaper. Alice is then hired as a governess, but on one condition: Argemiro would never see her:

não nos vermos senão quando isso fôr absolutamente indispensavel, ou melhor, não nos vermos nunca! A razão d'esta exquisitice, ou d'esta mania, não pôde ser explicada por in teiro em poucas palavras; supponha, porém, que repouza só nisto: não querer eu que paire so bre quem deve velar por minha filha nem a sombra de uma suspeita! (25).

By the end of the novel, Maria da Gloria finds in Alice a maternal figure; and Argemiro, a faithful wife. The end of the story stages the union of the master and the servant and the failure of the nobility to eradicate "intruders" from their domestic space. The Baroness holds a nostalgic-restorative vision of the aristocracy. Her moralizing gaze turns Alice into the source of all the ills of the republican regime. She embodies the traditional and nostalgic world of Imperial Brazil. She looks at the prospect of a secular education for 
Maria da Gloria as an unnecessary requirement for someone of noble origin: "Afinal, não se educa para doutora nem para professora. No meu tempo não se exigia tanto. .." (50). For Argemiro, the Baroness' feudal nostalgia contains a reactionary drive. As Svetlana Boym points out, restorative nostalgia stresses "a transhistorical reconstruction of the lost home rooted in "two main plots": "the return to origins and conspiracy" (3). As a utopian instance, "restorative nostalgia does not think of itself as nostalgia, but rather as truth and tradition" (3). In Almeida's novel, the Baroness grieves tradition while she suspects of the modern plebeian mass seeking a place of power in the emerging nation: "Uma governante! ...Por annuncio ! metteu em sua casa, na casa da milha filha, uma mulher por annuncio! E quer confiar-lhe a sua filha durante as horas ena que ella estiver na cidade? Oh ! meu amigo, isto não parece seu!" (53). But Argemiro ignores the Baroness' conspiratory plot. He opens the doors of his home to Alice. The "intruder" causes an irruption. She opens the space for a new political horizon in the republic, to a new bourgeois sensibility for the republic.

The presence of the intruder supposes a transgression in a feudal universe that already sees its sunset. Such anomaly that Alice's presence implies in the home of the nobility expresses the precarious imperial regime that begins to fade away. The presence of the bourgeois woman of dubious origin becomes diasporic. She is at home, she is in the street, she is in the slums and in the upper districts: "Mais essa! andar uma menina de boa familia, collada ás saias encardidas de uma mulher suspeita, por essas ruas da cidade! Não faltava mais nada. .." (107), the Baroness conspires. The Baroness' words are heard by the priest of the family, who is her confident: "Ah! Padre Assumpção, a Republica estragou nossa terra! Agora qualquer creatura parece digna de toda a confiança. . . Quem nos dirá quaes astenções d'aquella creatura? Por mim tenho medo, apesar da sua vigilancia..." (107).

The warning of the Baroness points to the danger of giving the control and integrity of the girl's body to a dubious maid. Almeida's campaign against governesses, which Roncador outlines in "O demonio familiar" finds expression in A intrusa. Alice marries Argemiro and becomes the lady of the house. With the story's resolution, Almeida warns the tragic future of noble girls before the death of their legitimate mother. Almeida, herself the daughter of a noble father, a doctor and Viscount of Valentine, in fact, presents a didactic program in $A$ intrusa. She advocates for the education of women but condemns the marital unions that ignore class lineage. The large houses of the old aristocracy with their slaves and servants had their racial, class and gender borders ensured. But bourgeois marriage does away with origin, tradition and blood. It blurs the rules of a world thought to be unalterable. Almeida sees the new Brazil invaded by a hybrid historical subject, whose legitimate power does not lie in its origin but in its ability to conquer adversity through good conduct and hard work.

The mystery of Alice, in fact, is discovered at the end of the novel. She is a young orphan, educated in France and the daughter of a lettered man. She emerges as an example of charity as she takes care of her old blind servant interned in a home. It is my intuition that Alice, a prototype of the fallen woman who recovers through her meritorious work, embodies the figure 
of the pious, sacrificial and maternal Victorian woman that the Republican regime requires for the new family and population design:

Esta moça, que toda a gente recebeu com certa malignidade, de eme eu não fui isento, exerce o encargo de governante d'esta casa para manter uma velha paralytica e um velho cego, verdadeiros cacos humanos, que ella visita todas as quarta-feiras piedosamente e de quem é o amparo. Filha unica de um advogado brasileiro, Constantino Galba e neta materna do General Vitalino Ortiz, logo que perdeu a mãe, foi man dada a educar num dos melhores collegios da França, onde viveu até que, por morte do pae, ficando quasi reduzida á miseria, voltou ao Brasil... A pobreza apura os dotes naturaes da creatura; ella trouxe para aqui a experiencia do sacrifício... (294).

The triumph of the exclusive monopoly of bourgeois morality in the novel proposes a consecration: that of the sacrificial, pious, and liberal family. The spiritualized, sublime inner life of Alice exorcizes the ghost of Maria, the deceased wife who torments Argemiro in his dreams. There would be no return to the feudal world of paternal relations between masters and slaves. There would be no expiation of a strange presence, that of the ignoble mass embodied by the governess. On the contrary, with the marriage of Argemiro and Alice, Almeida's novel, regardless of the author's beliefs, guarantees the reproduction of the new middle class, disciplined, self-governed, productive and a model of good conduct. In this sense, the resolution of the novel seems to complicate Almeida's stigmatization of the figure of the servant. With the construction of a pious and morally superior new female identity, the bourgeois woman quickly becomes compatible with the values of the nobility. It is discovered that Alice, far from being an intruder, is instead a class ally, a woman with an acquired legitimacy to be a stepmother for the landowning class. The class alliance between nobility and bourgeoisie is achieved in the text while the cautionary fable maintains its governmental objective: it is necessary to distrust the working class, its conduct and its bodies in order to preserve the reproductive futures of the elite.

\section{The Consolidation of the Governmental Fiction: Hóspede}

A intrusa staged the Brazilian family's capacity of self-government through the narration of a strong ethic of parental care. Yet the Brazilian writer and journalists Pardal Mallet (1864-1894), with his novel Hóspede (1887), would express the definitive triumph of what I call in this essay the governmental fiction. I want to claim that Mallet's depictions of the decline of illicit passions seems to consolidate the political fiction of heteronormativity and marriage. Mallet would observe the multiple constellations of the gentle and quiet, superficial and frivolous life of the Brazilian bourgeoisie. A forgotten fin-desiècle writer and a passionate figure of Carioca dandyism, he portrayed in Hóspede a costumbrista vision of a well-to-do existence.

On February 16, 1895, Valentim Magalhães wrote in Rio de Janeiro's newspaper $A$ semana the deep sorrow that caused him Mallet's death: 
"uma noticia secca e rápida como um golpe de martelo no pinho de um féretro" (3). Mallet and Magalhães had seen each other last at a banquet where Mallet looked "forte, alegre, bem disposto" (3). Mallet behaved as if he were a Victor Hugo's musketeer: Aramis, the obstinate frondeur, a lover of beautiful women and a gentleman of good conduct. He was a friend of the naturalist writers Olavo Bilac, Raul Pompeia, Coelho Neto, Luís Murat, José do Patrocínio, Artur and Aluísio Azevedo, Émile Rouède and Francisco de Paula Ney. He was twenty-nine years old when he died. He was a fervent republican and had enjoyed an accommodated life.

Mallet was a rebel, a gentleman, and a bohemian. A man of the late nineteenth century, he displayed with euphoria his political views in the newsrooms where he left his manuscripts that would be published for the "espanto da burguezia." During the night, he walked in "os jardins dos theatros, onde se trocavam brindes a champanhe em saudaçoes reciprocas" (Magalhães 3). Mallet descended from his carriages in the evenings to enjoy his cognac "e a fumar cigarros na maior cordialidade" (3) and then to duel as the honorable man that he was. Excessive, powerful and rich, between luxury and the weariness of good living, Magalhães's chronicle suggests that Mallet lived within the protected walls of Victorian leisure.

His journalistic work was pamphletarian and scandalous. His fiction was iconographic. As a polemicist, he stood out by being a furious republican and an abolitionist. La Gazeta da Tarde, Gazeta de Notícias, Diário de Notícias, A Rua, edited together with Luís Murat, Olavo Bilac and Raul Pompeia, contained his polemics and his outbursts. In relation to Mallet's work as a journalist, Magalhães wrote: "Tinha uma aptidao manifesta para a polemica e pronunciado pendor para o estudo das questões sociaes. Possuia boas qualidades de argumentador; mas como vulgarisador falleciam-Ihe faculdades essenciais, como methodo expositivo e claresa de expresão" (4). It can be argued that although banal in his journalistic work, in his novels Mallet became a remarkable iconographer of his social class. His novels describe the private rooms where the upper classes enjoyed their leasure time spent between banquets, cocktails, and flirtations. Mallet's governmental fiction in Hóspede talks about the exquisite art of the good government of conduct practiced by a social class in its plenitude. The novel leaves behind the pathologies of the ungovernable, hypersexualized bodies of morally corrupted characters to express instead the triumph of virtue.

Hóspede narrates the life of a family of the emerging middle class who lives in Rua do Ouvidor in fin-de-siècle Rio de Janeiro: Pedro, the patriarch, is a public official of the Secretary of Agriculture who lives with his wife Nenê, his mother-in-law D. Augusta, and his young son Pedroca. Pedro runs into Marcondes, an old classmate of the College Pedro II, from where they graduated with a law degree. Marcondes seeks accommodation in the city. Pedro invites him to stay at his house until Marcondes settles. But Marcondes would be an intrusive and impertinent guest. He tries to desecrate the home by entering into an adulterous relation with Nenê. Although the woman does not get to consummate the transgression, she actively flirts with the intruder to whom she finally rejects due to his indiscretions. The novel ends with the 
departure of the guest who looks with nostalgia at the weeks spent in Pedro's peaceful home, wishing to emulate his friends's conyugal life.

Mallet's novel would offer an iconographic portrayal of the Brazilian wellgoverned Victorian family. Afternoon tea, social gatherings, and rooms full of luxury and ostentation are combined with a daily scenario that, although monotonous and predictable, never deteriorates. In Hóspede, Mallet writes a soft naturalism of palatial customs where a strange guest, an intruder, invades the domestic space of a respectable family. The rest of the romance is a direct trip to the heart of the bourgeois room, its rituals, its clothes, its meals, its vague preoccupations sorted between cigars and cognacs and a clear desire to preserve the privilege of leisure time.

Mallet's main space would then be the sala de visitas: the living room, where decorous conduct speaks of the good government of manners:

Uma noite quando todos já se tinham retirado do portão, e, reunidos na sala de visitas, prestavam atenção a Nenê, que preludiava no piano uma romanza italiana, apareceu a visitá-los a família Moreira. Foram então uns grandes rebuliços, uns transbordamentos de alegrias. Havia tanto tempo que não se viam! E de parte a parte recomeçavam os beijos e os abraços, um desencadear sem fim de efusões ternas. O Marcondes foi imediatamente apresentado pelo Pedro ao Sr. Moreira - um sujeito alto e bem falante, já meio idoso, que ocupava uma posição elevada no funcionalismo. Logo em seguida, à voz de Nenê, que o chamava para o círculo das moças, ele dirigiu-se para junto do sofá onde recomeçaram as apresentações às filhas do tal sujeito. Eram três irmãs, muito galantes, de cabeças louras, os cabelos bastos e sedosos caindo despretensiosamente até a cintura. Trajavam igualmente uns elegantes vestidos de cetineta, com casacos de cetim arremedando fra- ques, quase disfarçadas em homens, com os competentes colarinhos e as gravatas com pregador em ferradura (96).

The passage reveals an exquisite, subtle, and sensitive atmosphere. Irreproachable conducts are sitting at the piano and overflowing with joy at the presence of equals in the world of leisure and good taste. Everything is diplomacy and courtesy in Mallet's interiors where the rich and powerful of Rio de Janeiro kiss and are kissed. The sala de visitas is the territory where Mallet's governmental program takes place. The sala is the extension of his own bohemian life. Outside, in the public universe of the newspapers, Mallet expresses vehemently his professive republicanism. But, in his novel, he writes his chronicles about the interiors of luxury and self-indulgence of well-behaved Victorian ladies and clubmen. In Hóspede, the villain Marcondes attempts to bring promiscuity into the blessed interior. But his gallantry and ritual of conquest of the lady of the house, Nenê, fails. She watches with jealousy the seductive exhibition of the intruder with the other female guests, 
Forcejava em atrapalhar todos os colóquios do Marcondes com a Linda; o rapaz, que notava estas súbitas transformações, fazia-se mais amável para excitá-la e provocar-lhe a tão ansiosamente esperada cena de ciúmes. A moça sentiase fora de si, não podendo compreender bem o que se passava no seu organismo. No final das contas ela gostava do Marcondes e percebera havia muito tempo que o rapaz lhe retribuía na mesma moeda! Nunca tivera a idéia de aceitá-lo para amante! Ela era muito honesta e não queria de forma alguma ser infiel ao marido! Mas o amor submisso e sossegado do moço lhe parecia muito decente, uma homenagem rendida à sua beleza vaidosa, homenagem recebida sem escrúpulos, nunca Ihe tendo passado pela idéia a possibilidade de uma exigência! $E$ agora zangava-se, não o queria para si, mas opunha-se também a que ele andasse requestando outras mulheres, entendendo que o rapaz tinha obrigação de dedicar-lhe uma contemplação gratuita de devoto! (97)

Two scenes combine the opacity of bourgeois life. The living room and the impulses of a frivolous class. Mallet exhibits the icons of the inner life of the bourgeoisie: jealousy, submission, decency, and devotion. He places his priorities. His governmental fiction stresses that clandestine passions can be well conducted with honesty and decency, as Nenê's actions indicate. There is no room for the consummation of a transgressive conduct in Mallet's fiction. The excessive pages of his naturalist colleagues devoted to pathologies and excesses of the flesh à la Zola are left behind. Hóspede delivers a vision of the wealthy Carioca class disaffected by the demons lurking in the bedrooms of hysterical ladies. I want to claim that, faced with the decadence, the tragedy, the blood and madness of physiological naturalist tales, Mallet's program of good conduct proposes a purge of Brazilian naturalism.

Against the immorality of the pornographic prose of the sensationalist Julio Ribeiro, Mallet would cover the pages with a new conscience able to exorcize desires able to destabilize the imperatives of intra-marriage reproductive sex and good family conduct. In Mallet, the bedrooms of the upper classes close their doors to adultery. Mallet's new fable of the respectable family is built upon the good government of conduct. The new protagonist of fin-de-siècle literature shall not be the body overflowed by sexual desire but the reproductive bedroom, the respectable wife, and the cordial man. The new naturalist inflection of good taste, pious conduct and intra-marital sex takes over the old grammar of French naturalism: casual pleasures, madness, adultery, and disorders of the flesh.

\section{Dramas of Virtue}

The notion of a governmental fiction allowed me to explore in this article how the late nineteenth-century Brazilian social tissue was staged in the series of novels here examined as an agglomeration of bodies in need of processes of normation and administration of conduct. The novels show the modes in which meanings are assigned to bodies marked by class, race, 
and gender difference. The naturalist novel drew distinctions between wellgoverned bodies able to conserve the political design of the Empire and of the Early Republic in contrast with libertine ones, those eager to transgress the program of the docilization of conduct. Brazilian naturalism conjugated European/colonial knowledges to understand local preocupations: the fall of the slave regime, urbanization, the emergence of the middle and proletarian classes, and the problem of the population. Literature, I want to suggest, became an art of government since, as Doris Sommer notes, "for the [Latin American] writer-statesman there could be no clear epistemological distinction between science and art, narrative and fact, and consequently between ideal projections and real projects" (7). A carne, A intrusa, and Hóspede present a literary map where corporeal borders are tightly controlled, where conflicts are sorted out by consolidating familial ties and by closing the social circles hierarchically organized by class, racial, gender, and sexual rationalities. Theses drama of triumph of bourgeois conduct supposes the consolidation of a program for the government of bodies and the production of disciplined and normative subjects of the emerging nation. Lenita, Alice, and Nenê are reduced to the task of reproducing the national family, educating the future generations of leaders and conserving the moral apparatus of the family.

The notion of governmentality applied to the study of naturalist fiction in Brazil allows to investigate the history of the arts of government situated at a particular geographical context (turn-of-the-century Brazil) while remaining faithful to Foucault's method. Governmentality considers that any history of power contains geopolitical borders. Foucault's own history of the arts of government is highly contextualized: pastoralism, raison d'etat, and liberalism are arts discovered through a precise empirical analysis of events resulting from historical circumstances in Europe, his locus of examination (Walters 69). Yet what Foucault's notion demonstrate is that no technology of government and power is essencially indigenous to the European context. As modernity is, in part, the history of global cultural transactions, I suggest that it is possible to think of French naturalism in the Brazilian cultural archive as the presence of an apparatus of security, as a European assemblage of knowledges and aesthetic experiments interested in the management of populations. Ultimately, Zola's experimental method, a clear source of inspiration for nineteenth-century Brazilian authors, seems to have been able to penetrate in the historical trajectory of fin-de-siècle Brazil through processes of transculturation to become an apparatus of government.

\section{Works Cited}

Agamben, Giorgio. Homo Sacer: Sovereign Power and Bare Life. Translated by Daniel Heller-Roazen. Stanford UP, 1998.

Remnants of Auschwitz: The Witness and The Archive. Translated by Daniel Heller-Roazen. Zone, 1999.

Almeida, Júlia Lopes. A intrusa. F. Alves, 1908. Web.

Araripe Jr., Tristão de Alencar. "A carne por Julio Ribeiro". Publicação no mensario Treze de Maio, Rio de Janeiro, Novembro, 1888, pp. 28-33; Dezembro, 1888, pp. 107-116. Em Obra crítica. Vol. II. 1888-1894.

Braga-Pinto, César. "Othello's Pathologies: Reading Adolfo Caminha with Lombroso." Comparative Literature, vol. 66, No 2, 2014, pp. 149-172. 
Boym, Svetlana. "Nostalgia and Its Discontents". The Hedgehog Review, vol. 9, No 2, 2007, pp. 7-18.

Butler, Judith. Precarious Life: The Powers of Mourning and Violence. Verso, 2006.

Deutscher, Penelope. Foucault's Futures: A Critique of Reproductive Reason. Columbia UP, 2017.

"Sacred Fecundity: Agamben, Sexual Difference, and Reproductive Life". Telos, No 161, 2012, pp. 51-78.

De Souza, Julianna Rosa. "Black Characters: A Critical Reflection about Racial Patterns in Dramaturgical Brazilian Production". Presença, vol. 7, No 2, 2017, pp. 274-295.

Edelman, Lee. No Future: Queer Theory and the Death Drive. Duke UP, 2004.

Foucault, Michel. Abnormal: Lectures at the Collège de France, 1974-1975. Edited by Arnold I. Davidson. Translated by Graham Burchell. Picador, 2003.

Psychiatric Power: Lectures at the Collège de France, 1973-74. Edited by Arnold I. Davidson. Translated by Graham Burchell. Picador, 2003. Security, Territory, Population: Lectures at the Collège de France, 1974-75. Edited by Arnold I. Davidson. Translated by Graham Burchell. Palgrave, 2007.

The History of Sexuality: The Will to Power. 1976. Translated by Robert Hurley. Penguin, 1992.

Lemke, Thomas. "Foucault, Politics and Failure". Foucault, Biopolitics, and Governmentality. Ed Jakob Nilsson \& Sven-Olov Wallenstein. Södertörn University, 2013.

Magalhães, Valentim. Flor de sangue. 1887. Universidade da Amazonia. Web. "Pardal Mallet". A semana. Ano VI. Tomo VI. Num. 72.16 de fevrero de 1895.

Mallett, Pardal. Hóspede; Lar / Pardal Mallet; [apresentação, Antonio Carlos Secchin; nota, Gilberto Araújo de Vasconcelos Júnior]. Rio de Janeiro: $A B L, 2008$.

Miranda, M. and Gustavo Vallejo. "Eugenesia e higiene mental: usos de la psicología en la Argentina, 1900-1940". Darwinismo social y eugenesia en el mundo latino, Siglo XXI de Argentina Editores, Buenos Aires, 2005.

Morel, Benedict Augustin. Traité des dégénérescences physiques, intellectuelles et morales de l'espèce humaine et des causes qui produisent ces variétés maladives. Atlas De XII Planches. J. B. Baillière, 1857.

Nordau, Max Simon. Degeneration. W. Heinemann, 1895.

Ribeiro, Julio. A carne. 1887. F. Alves. Web.

Rodrigues de Oliveira, Lucélia. "Nos domínios da carne: Júlio Ribeiro, Sena Freitas e a polêmica no século XIX", http://www.uel.br/eventos/ sepech/sumarios/temas/nos_dominios_da_carne_julio_ribeiro_sena_ freitas_e_a_polemica_no_seculo_xix.pdf. Web.

Roncador, Sônia. "O demônio familiar: lavadeiras, amas-de-leite e criadas na narrativa de Júlia Lopes de Almeida". Luso-Brazilian Review 44.1 (2007): 94-119. Web.

Scull, Andrew. Hysteria: The Biography. Oxford University Press, 2009.

Schlickers, Sabine. El lado oscuro de la modernizacion: Estudios sobre la novela naturalista hispanoamericana. Iberoamericana Vervuert, 2003.

Sommer, Doris. Foundational Fictions: The National Romances of Latin America. U of California P, 1991. 
Süssekind, Flora. Tal Brasil, Qual Romance?: uma ideologia estética e sua história : o naturalismo. Achiamé, 1984.

Zola, Émile. Théresè Raquin: A Realistic Novel. 1867. Vizetelly, 1887. The Internet Archive, https://archive.org/details/cu31924027431455

Walters, William. Governmentality: Critical Encounters. Routledge, 2012. 
